\title{
PERFORMANCE OF SQUARE FOOTING RESTING ON LATERALLY CONFINED SAND
}

\author{
A. Krishna ${ }^{1}$, B. Viswanath ${ }^{2}$, Nikita Keshav ${ }^{3}$ \\ ${ }^{1}$ Asst. Professor, Department of Civil Engineering, University Visvesvaraya College of Engineering, Bangalore, \\ Karnataka, India, \\ ${ }^{2}$ Asst. Professor, Department of Civil Engineering, University Visvesvaraya College of Engineering, Bangalore, \\ Karnataka, India \\ ${ }^{3}$ Former ME Student, Department of Civil Engineering, University Visvesvaraya College of Engineering, Bangalore, \\ Karnataka, India
}

\begin{abstract}
The load carrying capacity of a model square footing resting on sand has been studied. Footing is confined laterally with the help of mild steel plates welded to form a hollow box of different depths. The effect of embedment depth of footing on the load carrying capacity and settlement values has been studied. Varying depth of confinement, relative density, embedment depth of footing ratio was utilized. Based on the results obtained, load versus settlement curves are plotted and it is observed that, as the depth of confinement increases, the load carrying capacity of the footing also increases.
\end{abstract}

Keywords: Sand, Mild steel Hollow Box and Relative Density

\section{INTRODUCTION}

A shallow foundation is one that is located at, or slightly below, the surface of the ground. A typical foundation of this type is seen in the shallow footings, either of plain or reinforced concrete, which may support a building. Footings are generally square or rectangular. Long continuous or strip footings are also used, particularly beneath basement or retaining walls. Another type of shallow foundation is the raft or mat; it may cover a large area, perhaps the entire area occupied by a structure. India has seen increasing growth in infrastructure development in the last decade. The decreasing availability of good construction sites is forcing engineers to utilize even the poorest sites with weak subsoil conditions. The poor ground conditions pose the problem of low shear strength leading to low bearing capacity as well as high compressibility resulting excessive settlements occurring over long periods of time. The presence of large deposits of weak soil of varying nature has necessitated the development \& application of various ground improvement techniques.

The confinement material can be of different types. One such common type used in improving the bearing capacity of soil or sand is cellular confinement systems. Cellular Confinement Systems (CCS, also known as geocells) are widely used in construction for erosion control, soil stabilization on flat ground and steep slopes, channel protection, and structural reinforcement for load support and earth retention. Typical cellular confinement systems are made with ultrasonicallywelded high-density polyethylene (HDPE) or Novel
Polymeric Alloy (NPA) strips that are expanded on-site to form a honeycomb-like structure which may be filled with sand, soil, rock or concrete. Laboratory plate loading tests on geocells showed that the performance of geocell-reinforced bases depends on the elastic modulus of the geocell. The geocell with a higher elastic modulus had a higher bearing capacity and stiffness of the reinforced base. Geocells made from NPA were found significantly better in ultimate bearing capacity, stiffness, and reinforcement relative to geocells made from HDPE.

The effect of sand confinement on the behaviour of shallow foundations has been investigated through loading confined sand specimens, testing foundation models resting on laterally or vertically confined sand. Much literature is available is this; some of them are listed below.

Centrifuge tests were conducted Kutter, B.L., Abhari, A., and Cheney, J.A in 1988, on concentric loading of circular footings on dense sand. Results concluded that except for $1-\mathrm{g}$ test, all three methods of determining the strength parameters appear to yield adequate predictions of bearing capacity. De Beer's method and the newly proposed $c-\phi$ method give excellent agreement between predicted and measured bearing capacities. Experimental study concerning a method of improving the bearing capacity of strip footing resting on sand subgrades utilizing vertical nonextensible reinforcement were studied by M.A.Mahamoud and F.M.Abdrabbo in 1989. Results concluded that utilizing nonextensible reinforcing elements installed along each side of a strip footing was found 
to be good method of increasing the bearing capacity of the footing soil system. The model tests were conducted in a steel tank with a length of $1200 \mathrm{~mm}$, width of $332 \mathrm{~mm}$ and height of $700 \mathrm{~mm}$ by Sujit kumar Dash, N. R. Krishnaswamy, K. Rajagopal in 2001. The soil used in the study is classified as poorly graded sand. The results concluded that, the pressuresettlement behaviour of strip footing resting on geocellreinforced sand is approximately linear even up to a settlement of about $50 \%$ of the footing width and a load as high as 8 times the ultimate capacity of the unreinforced one. AlAghbari, M.Y., and Mohamedzein, Y.E 2004 studied the modified bearing capacity equation is proposed for skirted strip foundations on dense sand. A series of tests on foundation models were carried out to study the factors that affect the bearing capacity of foundations with skirts. The results obtained from the proposed equation were compared with the results obtained from Terzaghi, Meyerhof, Hansen and Vesic bearing capacity equations for foundations without skirt. Comparison shows that the use of structural skirts can improve the bearing capacity by a factor of 1.5 to 3.9 depending on the geometrical and structural properties of the skirts and foundation, soil characteristics and interface conditions of the soil-skirt-foundation system. Laboratory model tests on the influence of soil confinement on the behaviour of a model footing resting on granular soil were conducted by M. EI Sawwaf and A. Nazer in 2005. The results indicated that the bearing capacity of circular footing can be appreciably increased by soil confinement. It was also concluded that increasing the height of the confining cell, results in increasing the surface area of the cell-model footing, which footing load to deeper depths and leads to improving the BCR. The behaviour of shallow foundations resting on laterally and vertically confined sand has been investigated by Hisham T. Eid, Omar A. Alansari, Husam A. Sadek et al; in 2009 using physical and numerical modeling. The models were designed to simulate the frequently constructed raft foundations that are surrounded by sheet pile walls to support excavation sides of sand underlain by a rock bed. Based on the results of the experimental and numerical analysis, charts are presented to estimate the enhanced bearing capacity of square foundations resting on confined sand. These charts are presented in terms of bearing capacity of the surface foundation resting on extended sand, sand relative density, wall width to foundation width ratio and rigid layer depth. Results also concluded that Existence of the wall and rigid stratum can significantly reduce settlement of shallow foundations resting on sand.

\section{OBJECTIVE OF THE STUDY}

The objective is to study the load carrying capacity of sand at three different relative densities. To study the effect of square footing on laterally confined sand bed. To study the effect of embedment depth of footing within confinement of different depths on its load and settlement values. To study the behaviour of existence of rough rigid layer and the confining material on the load carrying capacities and settlement values of the footing.

\section{MATERIALS AND METHOD}

Due to the rapid growth of infrastructural facilities, there is a need to upgrade the construction activities in areas with poor subsoil conditions. Bearing capacity of loose sand is very low and settlement is high. Instead of using pile foundation, shallow foundation can be provided by improving the properties of sand with a confinement around the footing.

\subsection{Sand}

Locally available sand is taken for the present study. Particle size distribution is shown in the figure below. Sand has uniformity coefficient $\left(\mathrm{C}_{\mathrm{u}}\right) 3.06$ and coefficient of curvature $\left(\mathrm{C}_{\mathrm{c}}\right) \mathrm{1.304}$, thus sand is considered as uniformly or poorly graded sand. Specific gravity of sand is 2.575 and it has a maximum and minimum dry density of $17.55 \mathrm{kN} / \mathrm{m}^{3}$ and $15.85 \mathrm{kN} / \mathrm{m}^{3}$ respectively. The angle of internal friction used for the study is found to be $\Phi=36^{\circ}, 40^{\circ}, 42^{\circ}$ respectively for $\mathrm{R}_{\mathrm{d}}=0.25,0.5,0.75$. The particle size distribution of sand used in the present study is shown in figure 1 below.

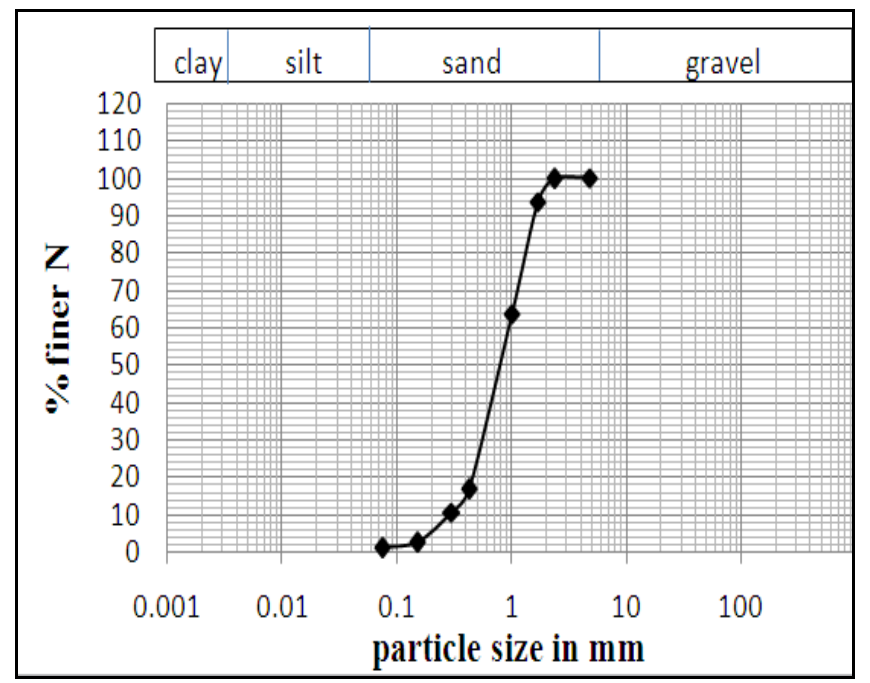

Fig -1: Grain Size Distribution Curve of Sand

\subsection{Mild Steel Casing}

Mild steel square hollow box of size $90 \mathrm{mmX} 90 \mathrm{mmX} 3 \mathrm{~mm}$ with varying heights of 30,60, 90, 120 and 150mm were used. The pictorial view is shown in figure 2 . 


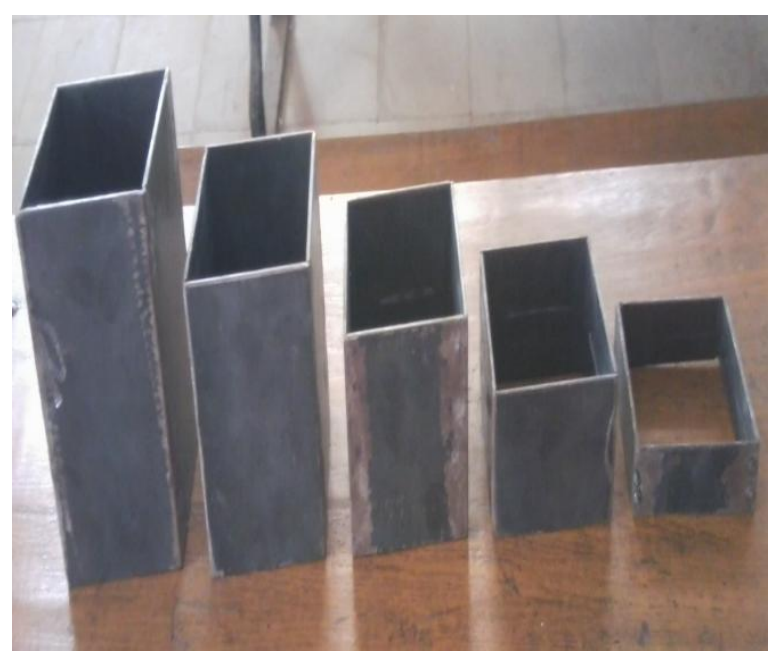

Fig-2: Mild Steel Casing

\section{EXPERIMENTAL PROGRAMME}

Experiments were carried out to determine the settlement and bearing capacity of square footing of size $75 \mathrm{mmX} 75 \mathrm{mmX} 20 \mathrm{~mm}$ resting on sand which is placed in a square tank of size $500 \mathrm{mmX} 500 \mathrm{mmX} 500 \mathrm{~mm}$ with three relative densities.

A total of 48 tests were conducted on sand layer. The experimental programme is as shown in figure 3 .

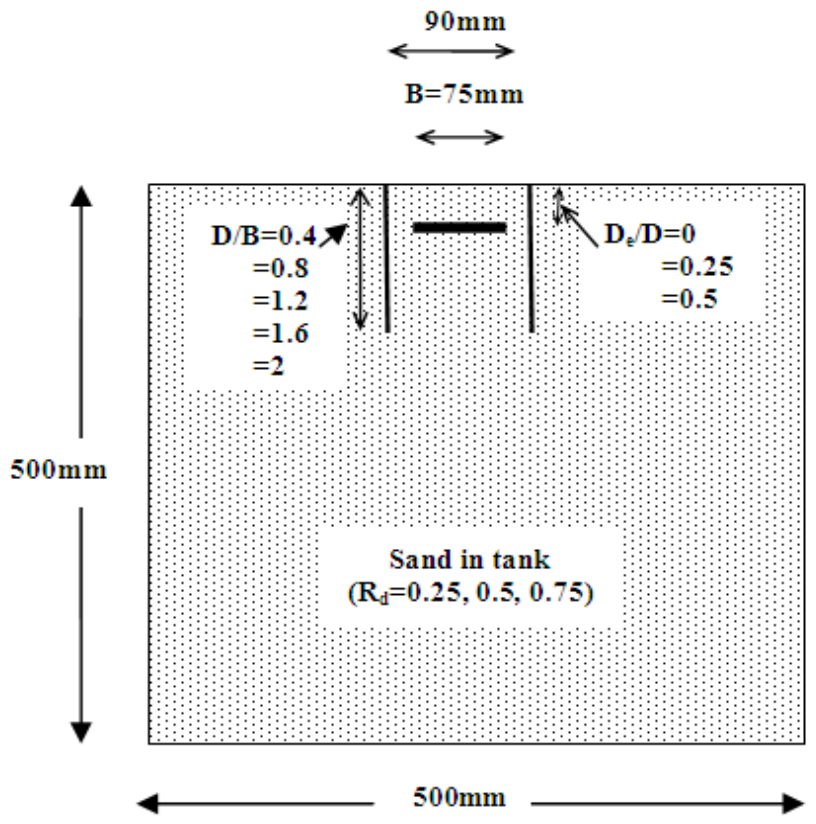

Fig-3: Square Foundation Model with Confinement and Ranges of the Parameters to Be Studied

\subsection{Preparation of Sand Bed and Placement of the Confining Cell}

Poorly graded sand was used as foundation soil in this testing program. The tank was divided into five equal layers each of $100 \mathrm{~mm}$ depth, except the last layer. In order to avoid spilling of the particles while compacting last layer, a clearance of about $30 \mathrm{~mm}$ is given. Calculating the natural density required for the three different relative densities used for the testing program, the weight of sand required for each layer is calculated. Measured sand was uniformly poured and spread into the tank. A manual tamping was needed to achieve the required density. Similarly tank is filled in five layers. The open ended mild steel square hollow box was first forced into the sand bed followed by centering the associated model footing on the surface of sand layer. In case of $D_{e}>0$, excavation was needed inside the inserted model hollow box to a depth $\mathrm{D}_{\mathrm{e}}$ before placing the foundation model. Confining cell and model footing were placed and then load is applied

Selecting a constant rate of strain of $1.2 \mathrm{~mm} /$ minute, a vertical compressive load was applied. The proving ring readings corresponding to dial gauge readings were recorded up to failure. The load versus settlement graph is plotted for each of the testing program.

\section{RESULTS AND DISCUSSION}

Foundation model tests were conducted on laterally and vertically confined sand prepared at three different relative densities as per the experimental program. The load-settlement relationships for footing with and without confinement were obtained. The load carrying capacity of confined and unconfined sand is taken as the load intensity corresponding to $30 \mathrm{~mm}$ settlement. The percentage improvement in load carrying capacity of confined sand over unconfined sand is calculated and presented in the table

Figure 4 shows the load settlement relationship for the footing resting on sand surface with relative density of $75 \%$ for various $\mathrm{D} / \mathrm{B}$ values. It is observed that, as the depth of confinement increases the load carrying capacity of the footing increases. Footing sustains a maximum load for $\mathrm{D} / \mathrm{B}=2$. The load carrying capacity of the surface footing resting on sand with and without lateral confinement is more compared to that with relative density 0.25 and 0.5 . It is also observed that, considerable increase in load carrying capacity of footing was observed for $R_{d}=0.75$ compared to that with $\mathrm{R}_{\mathrm{d}}=0.5$ without lateral confinement. However with confinement the increase in load carrying capacity is marginal. Thus, for surface footing, if depth of confinement to width of footing ratio is 2 (i.e. $\mathrm{D} / \mathrm{B}=2$ ) then the footing performs better. 


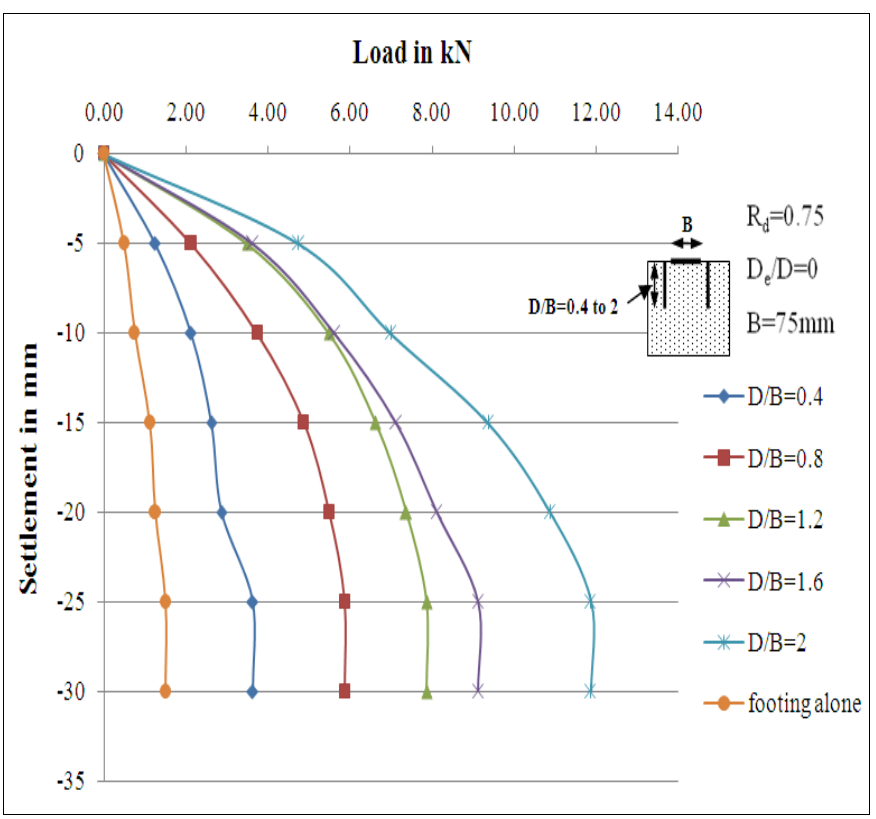

Fig- 4: Load Settlement Response of Square Footing with and Without Lateral Confinement

Figure 5 shows the load carrying capacity of the surface footing resting on sand with $\mathrm{R}_{\mathrm{d}}=0.25,0.5$ and 0.75 and for various D/B ratios. From the graph it is observed that, the increase in load carrying capacity of surface footing resting on sand with $R_{d}=0.25$ and $R_{d}=0.5$ without lateral confinement is marginal. However the increase in load carrying capacity of surface footing without confinement is considerable for $\mathrm{R}_{\mathrm{d}}=0.75$. Also the load carrying capacity of footing with lateral confinement for medium dense and densest state of sand layer (i.e. $R_{d}=0.5$ and 0.75 respectively) is more than that for loosest state. Whereas, increase in load carrying capacity of surface footing for $\mathrm{R}_{\mathrm{d}}=0.5$ and 0.75 is marginal. Also there was about $180 \%$ improvement in load carrying capacity was observed for $R_{d}=0.25$ and about $16 \%$ for $R_{d}=0.5$ compared to that of footing resting on sand with $R_{d}=0.75$. As the confinement material is pushed into the sand layer, the air voids will be reduced there by increasing the density of sand and hence the load carrying capacity of footing increases. However the effect of lateral confinement on load carrying capacity of footing resting on densest state of sand is insignificant.

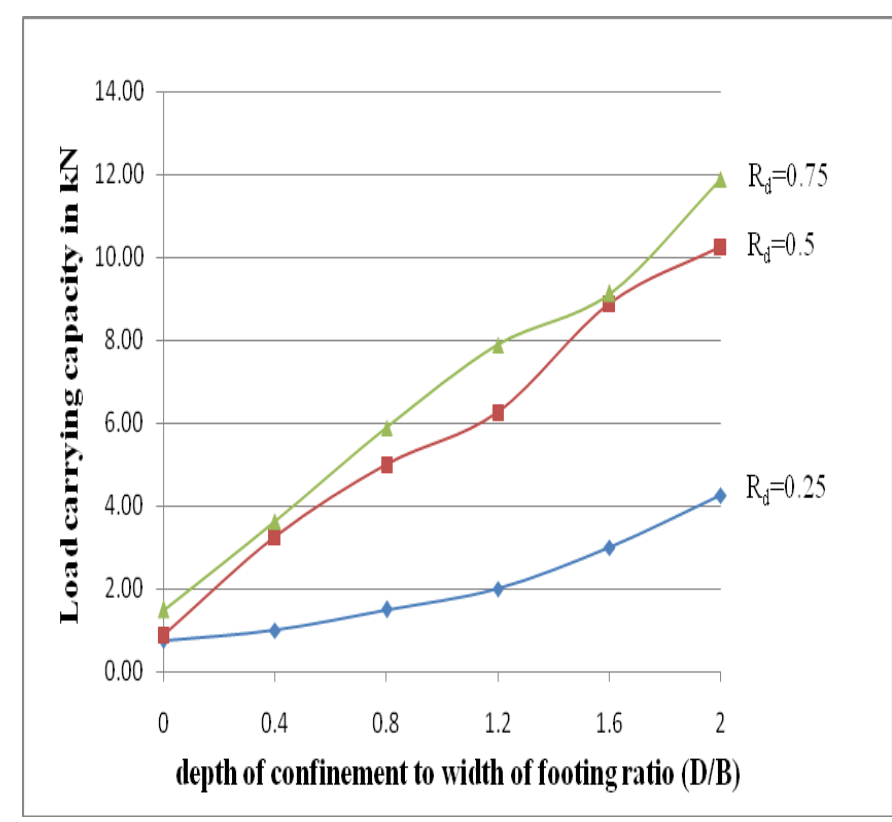

Fig- 5: Comparison of Load Carrying Capacity of Surface Footing $\left(D_{\mathrm{e}} / \mathrm{D}=0\right)$ with and Without Lateral Confinement for $\mathrm{R}_{\mathrm{d}}=0.25,0.5,0.75$ and for Varying D/B Ratios

Figure 6 shows the load settlement response of square footing embedded within confinement for $R_{d}=0.5, D_{e} / D=0.5$ and for varying $\mathrm{D} / \mathrm{B}$ ratios. It is observed from the graph that as the depth of confinement increases, the load carrying capacity of the embedded footing also increases.

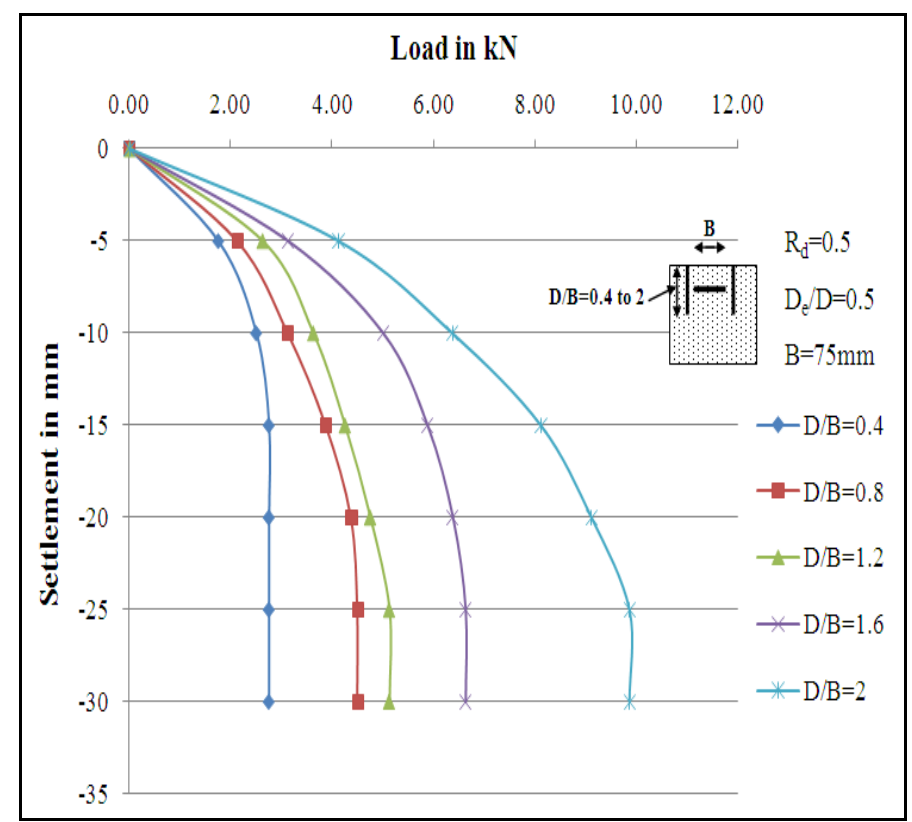

Fig- 6: Load Settlement Response of Square Footing Embedded within Confinement for $\mathrm{R}_{\mathrm{d}}=0.5, \mathrm{D}_{\mathrm{e}} / \mathrm{D}=0.5$ and for varying D/B Ratios 
However, decrease in load carrying capacity of the embedded footing with lateral confinement was observed compared to that of surface footing with lateral confinement. Because, as the embedment depth of footing increases, the depth of confinement below the footing decreases, there by reduction in the load carrying capacity of footing reduces.

Figure 7 shows the load carrying capacity of the footing resting on laterally confined sand at three different relative densities i.e. $R_{d}=0.25,0.5,0.75$ and for varying $D_{e} / D$ ratios. The load carrying capacity of footing at lateral confinement of $\mathrm{D} / \mathrm{B}=2$, increases with the increase in $\mathrm{D}_{\mathrm{e}} / \mathrm{D}$ ratios and relative densities. However, marginal increase in load carrying capacity of the embedded footing was observed from $\mathrm{D}_{\mathrm{e}} / \mathrm{D}=0.25$ to 0.5 . Also the improvement in the load carrying capacity of the footing is marginal from $\mathrm{R}_{\mathrm{d}}=0.5$ to 0.75 . However, maximum load carrying capacity was observed for the footing embedded at a ratio of $\mathrm{D}_{\mathrm{e}} / \mathrm{D}=0.5$ at $\mathrm{R}_{\mathrm{d}}=0.75$.

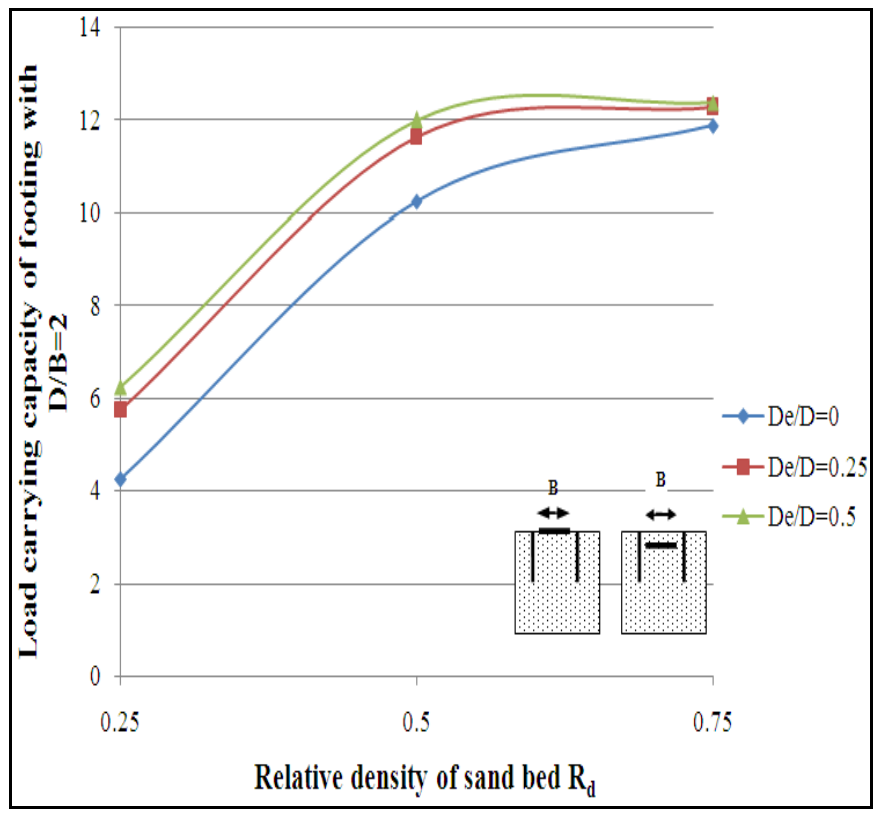

Fig- 7: Comparison of Load Carrying Capacity of Footing with Only Lateral Confinement of $D / B=2$ and for Varying $R_{d}$ and $\mathrm{D}_{\mathrm{e}} / \mathrm{D}$ Ratios

\section{CONCLUSIONS}

Based on the experimental results the following conclusions are drawn.

- In case where structures are sensitive to settlement, confinement can be used to obtain the same allowable bearing capacity at a much lower settlement.

- Load carrying capacity of the footing increases due to the existence of confinement.

- As the depth of confinement increases, the load carrying capacity of the square footing increases when compared to that of surface footing without confinement and was found to be maximum at $\mathrm{D} / \mathrm{B}=2$.

- As the embedment depth of the footing increases, the load carrying capacity of the footing also increases. It was found to be maximum at $\mathrm{D}_{\mathrm{e}} / \mathrm{D}=0.5$ for all the three relative densities with both vertical and lateral confinement.

- Increasing the depth of confinement results in increasing surface area of the confinement-model footing, which transfers footing loads to deeper depths and leads to improvement in load carrying capacity.

- Based on experimental results, soil confinement could be considered as a method to improve the bearing capacity of isolated footings resting on loose to medium dense sand.

\section{REFERENCES}

[1] Al-Aghbari, M. Y., and Mohamedzein, Y.E.-A (2004). Bearing capacity of strip foundation with structural skirts. Geotechnical and Geological Engineering, Vol. 22, pp.43-57.

[2] Cereto A. B and A. J. Lutenegger (2006). Bearing capacity of square and circular footings on a finite layer of granular soil underlain by a rigid base. Journal of geotechnical and geoenvironmental engineering ASCE, Vol. 132(11), pp. 1496-1501, Vol. 132(11), pp. 14961501.

[3] EI Sawwaf, M., and Nazer, A (2005). Behaviour of circular footing on confined granular soil. Journal of geotechnical and geoenvironmental engineering ASCE, Vol. 131, pp. 359-366.

[4] Hisham T. Eid, Omar A. Alansari, Husam A. Sadek et al ;(2009). Comparative study on the behaviour of square foundations resting on confined sand. Canadian geotechnical journal, Vol. 46, pp. 438-453.

[5] Kutter, B.L., Aghbari, A., and Cheney, J.A (1988). Strength parameters for bearing capacity of sand. Journal of geotechnical engineering ASCE, Vol.114, pp. 491-497.

[6] Mahamoud, M.A., and Abdrabbo, F.M (1989). Bearing capacity tests on strip footing on reinforced sand sub grade. Canadian geotechnical journal, Vol. 26, pp. 154159.

[7] Sujit kumar Dash, N. R. Krishnaswamy, K. Rajagopal (2001). Bearing capacity of strip footings supported on geocell-reinforced sand. Geotextiles and geomembranes, Vol. 19, pp. 235-256. 